\title{
Using Activity Theory as Analytical Framework for Evaluating Contextual Online Collaborative Learning
}

\author{
http://dx.doi.org/10.3991/ijet.v9i5.3972 \\ Mohd Nihra Haruzuan Mohamad Said, Lokman Mohd Tahir, Mohd Fadzli Ali, \\ Norah Md Noor, Noor Azean Atan, Zaleha Abdullah \\ Universiti Teknologi Malaysia, Malaysia
}

\begin{abstract}
In this article, Activity Theory is used as analytical framework for developing and evaluating the model of contextual online collaborative learning. Activity Theory is useful particularly because it provided the researcher with tool to structure human activities in relation to computer within a context. As in the context of this study, Activity Theory proved to be useful for developing and evaluating the incorporation of online collaborative learning within a particular chosen context, i.e. conventional tertiary classroom. Discussions on findings based on the analysis of contextual online collaborative learning are also provided.
\end{abstract}

Index Terms-E-learning system; Activity Theory, Online Collaborative Learning; ICT Education.

\section{INTRODUCTION}

The "heart and soul" of an online learning is collaboration [13]. Online learning through collaboration is often quoted as online collaborative learning, which happens to be an umbrella term for an instructional strategy that emphasizes active knowledge construction through mutual efforts by students via the internet. Usually in online collaborative learning, students are expected to work together towards the whole knowledge construction process and learning, not only to appreciate their own work but also contributions of their peers [6][7].

Online collaborative learning, more or less is a philosophy of interaction of how students actually work together online, rather than how teachers wish they will work together [6]. Online collaborative learning represents a significant shift away from the typical teacher-centered approach, where social interactions are emphasized. The context of social interactions has shifted from merely a background for individual activity to a focus of research, where it has become a unit of analysis [10][16]. Research on distance education reveals that online collaborative learning through its electronic technology has advantages of interactions and communications over face-to-face collaboration [6][7]. Through online settings, collaborative interactions among students are becoming easier to manage and monitor. Students are able to read others' responses and at the same time participate by adding their own opinions and ideas to discuss and solve problems [9][13][15].

While the focus of online collaborative learning is emphasized through the outcomes of student interacting and participating online, in reality most (if not all) of online collaborative learning interactions particularly within conventional classroom are usually demoted to discussion forum conversations, in which students are merely posting chat about their weekly course topics, which limits the extent of actual collaboration. Teachers also often instruct students to form small groups, hoping that students will collaborate, but this is not always the case. Simply assigning students to groups does not guarantee that meaningful online collaborative learning situation would occur. Additionally, students that participating and interacting in online collaborative learning could also easily meet faceto-face due to the nature of conventional classroom context that allows face-to-face offline interactions to occur which actually will have some influenced on their learning [11][12].

Hence, this paper is intended to shed light on the process of incorporating online collaborative learning in a conventional classroom using Activity Theory as analytical framework for developing and evaluating the model of contextual online collaborative learning. Activity Theory proves to be useful because it provides a structure for conceptualizing human practices in relation to a computer within a context (e.g. online learning) [3][5]. Moreover, Activity Theory is increasingly being used within the area of research such as social sciences and computer interaction, in research into distributed cognition and, for designing online learning setting or e-learning environment [10][16]. In the following section the description of Activity Theory that was used in developing the online collaborative learning model is elaborated upon.

\section{LITERATURE REVIEW}

The Cultural-Historical Activity Theory or known as Activity Theory is a theoretical perspective that highlights learning as cultural activities that are mediated by cultural artifacts [3][5][16]. Cultural artifact in this paper is intended to mean tools (e.g. computer software, procedures, methods, rules, forms of work organization) that have their own mediating role and carry a particular culturehistorical residue [8]. It is somehow agreed among social learning researchers that today knowledge is no longer perceived as the outcome of an individual mind but as a collective outcome based on the contribution of different individual minds involved in different activities [5][16].

Despite the confusion associated with the term, Activity Theory refers to the Soviet cultural-historical research that represents neither activity nor theory in general. The core concept or basic unit of Activity Theory is still called activity in which it carries a minimal meaningful context 
for individual actions [3]. It is through activities that humans develop skills, personalities and consciousness, transform social conditions, resolve contradictions, generate new cultural tools, and create new forms of life and the self [14]. Some researchers also believe that through such activities humans transform learning and embrace the possibility of expansive learning [5]. Rogoff [14] asserts human development is a cultural process, and has a great influence on the content and course of development and learning.

Activity Theory views learning as inseparable from activity; activity is not carried out by the human alone but mediated by tools within a cultural-historical context. Engeström [5] argues against behavioral and social science researchers that separate the study of the human activity and his or her cultural tools from the study of individual behavior and human agency. He believes that human activity is never isolated and separated from cultural tools and made it clear in his writing that "the individual could no longer be understood without his or her cultural means; and the society could no longer be understood without the agency of individuals who use and produce tools" [4, p. 134]. He points out the key to understanding the human mind is through the objectorientedness of action between human and object through mediating tools.

Activity Theory has evolved through different generations. The first generation of Activity Theory traces its history from the early works of Vygotsky, Leont'ev and Luria [3][5][16]. Vygotsky and others developed the concept of mediation which serves as the core of the first generation of Activity Theory. The mediation model advocated by Vygotsky encompasses two basic components called stimulus $(\mathrm{S})$ representing subject, and response (R) representing object. The relationship between the stimulus or subject and response or object is mediated by an intermediate term called a mediating tool which carries with it the history of the relationship [8]. When the object is transformed the outcome is produced as depicted in Fig.1.

However, the process of transformation as depicted in Fig. 1 is limited because the main unit of analysis only occurs at the individual level, which is missing the component of collective activity [4]. Inspired by Leont'ev's famous example of primeval collective hunt, Engeström presents a much more integrated model of a collective human activity system that borrows Leont'ev's explication of the crucial differences between an individual action and a collective activity. Engeström defends his action by claiming that Leont'ev never explicitly expanded Vygotsky's model into a triangular model of a collective activity system as depicted in Fig. 2.

In this triangular model, the insertion of community into the first model of Activity Theory is to illustrate the collective (or society) level of activities. Engeström [4] calls the top side of the sub-triangle "the tip of the iceberg" which acknowledges activity at the individual level, and the opposite of the top sub-triangle as "group actions embedded in a collective activity system" (p.134). The triangular model consists of two overlapping triangles, known as the external (outer) triangle and the internal (inner) triangle. The external triangle of the triangular model encompasses the components of the tool, rules and division of labor, while the internal triangle encompasses subject, object and community. The mutual relationship between components in the external triangle and internal

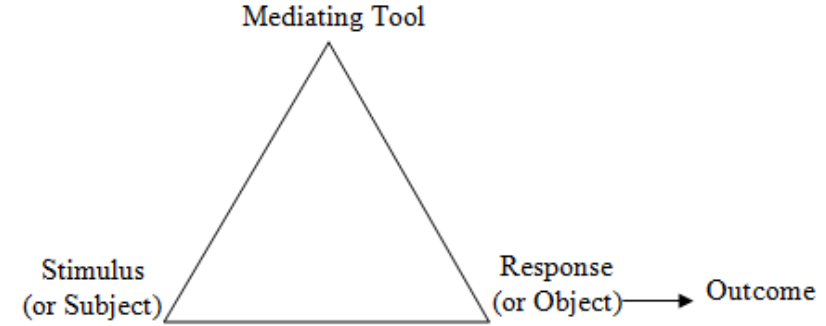

Figure 1. First generation of Activity Theory [4]

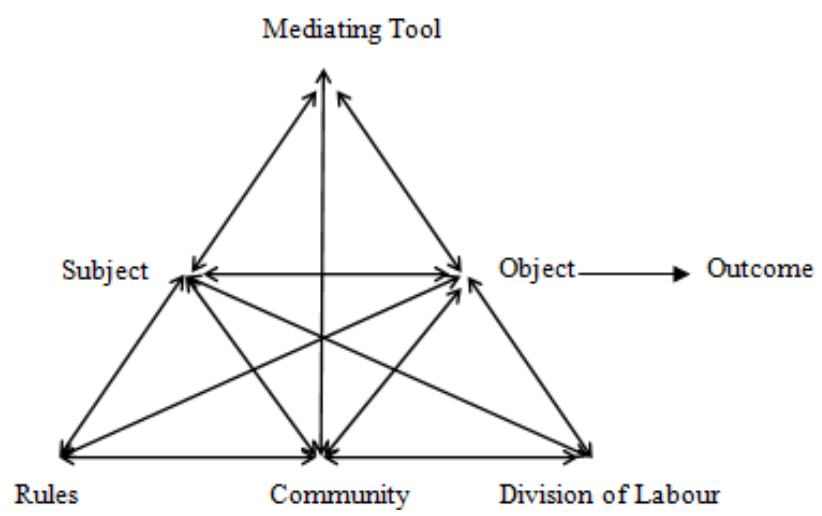

Figure 2. Second generation of Activity Theory [5]

triangle can be explained in a systemic and interrelated manner where the relationship between subject and object is mediated by the tool, the relationship between subject and community is mediated by rules, and the relationship between object and community is mediated by division of labor. In the context of Activity Theory, "rules" is intended to mean "the explicit and implicit regulations, norms and conventions that constrain actions and interactions within the activity system" and "division of labor" means "both the horizontal division of tasks between the members of the community and the vertical division of power and status" [4, p. 67].

An activity system does not exist in a vacuum and is never constructed ex nihilo (or out of nothing) but it is situated within and between activities and relies on the language, tools or equipments, institutions and conventions) [1]. In order to develop framework for evaluating an online collaborative learning, therefore, we must examine not only the kinds of learning activities that people engage in but also who is engaging in that activity, what their goals and intentions are, what objects or products result from the activity, the rules and norms that circumscribe that activity, and the larger community in which the learning activity occurs [16]. Activity is the core essence of human functioning. Activity is also centered by the interaction of minds in the world, socially constructing and sharing meaning [3][14]. Consequently, it drives human life towards participation in an object-oriented activity [3].

\section{MODEl For Evaluating OnLINE COLLABORATIVE LEARNING}

Engeström [5] argues that when two or more activity systems interact there is a possibility for a third space to emerge. This space can be assumed to be a door that opens for "events in classroom discourse where the seemingly self-sufficient worlds and scripts of the teacher and the students occasionally meet and interact to form new meanings that go beyond the evident limits of both" ( $p$. 
136). In this study, the nature of how students work together towards their project completion is described diagrammatically, as depicted in Fig. 3.

The single group represents an activity system in which all elements constantly interact with one another and are virtually always in the process of working through changes. Changes in the design of a tool may influence a subject's orientation towards an object, which, in turn, may influence the cultural practices of the community. In addition, it is possible that the object and motive themselves will undergo changes during the process of activity [8]. When the single activity system is forced into interacting with other activity in a particular context, it will result in the development of what Engeström [5] calls "the third object" which indicates a potentially shared or jointly constructed object. Fig. 4 illustrates initial working model for online collaborative learning within a conventional classroom context.

The analytical framework to identify the transformative outcomes experienced by students as a result of their participation in online collaborative learning activities can be conducted at higher, middle and lower contextual levels [1]. The higher contextual level refers to an analysis in a broader cultural institutional context within which the intervention takes place, followed by a middle contextual level of analysis within the intervention, and then an evaluation of the analysis of the intervention as to its outcomes and constraints at the lower contextual level in order to reveal its temporal interconnectedness. Fig. 5 depicts these processes.

Description of related aspects for contextual online collaborative learning model are distilled in accord to Fig. 5 and summarized as follows (see Fig. 6):

- The higher level (class) - analysis of the intervention on a broader institutional contextual level within which the intervention operates. The affordance of tools, activities and resources for participations in the course and how these affected students' expectations from the course and how they have achieved the goals.

- The middle level (group) - analysis of the intervention on the aspects of students' distributed online interactions to the course. How students interact one to another at the same time personalizing their own interactions for collaboration during the intervention to achieve the course goals.

- The lower level (outcomes) - analysis of the intervention is discussed in terms of its outcomes and constraints on students' participation in the activities. The outcomes are marked as cognitive, social, and emotional transformations.

\section{Methodology}

The study is guided by qualitative interpretive methodology that attempts to explain the reality, not through universal laws of knowledge but through understanding the complex interactions of the students experiencing the online collaborative learning and their understanding of the desired learning outcomes. According to Cohen, Manion and Morrison [2], the central endeavor of the interpretive paradigm is to understand the subjectivity of human experience within its context.

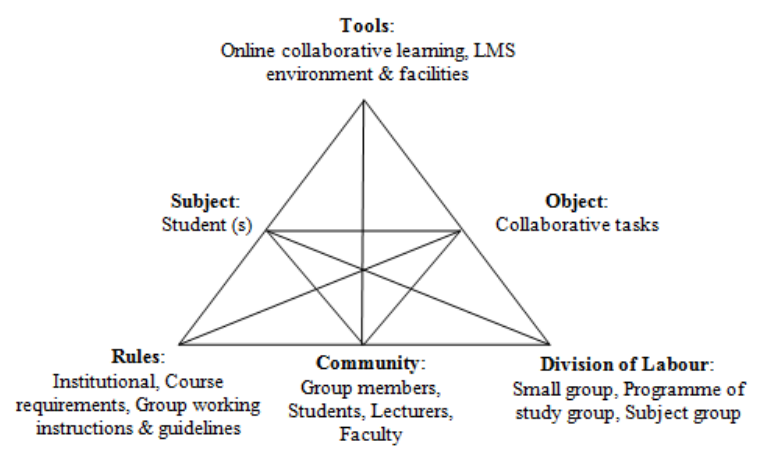

Figure 3. The aspects for the study

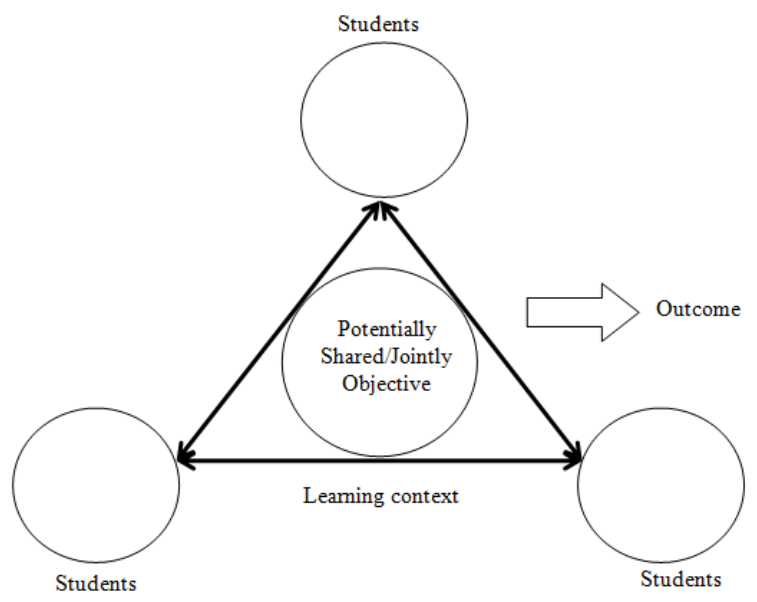

Figure 4. Initial working model for the study

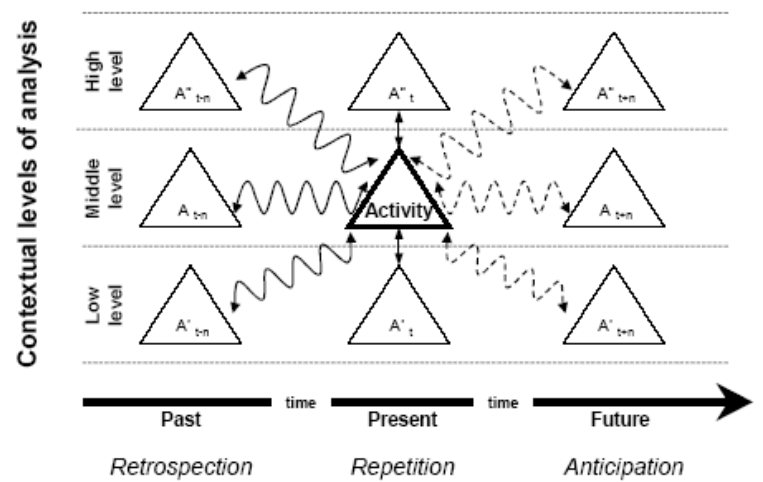

Figure 5. The contextual analytical framework

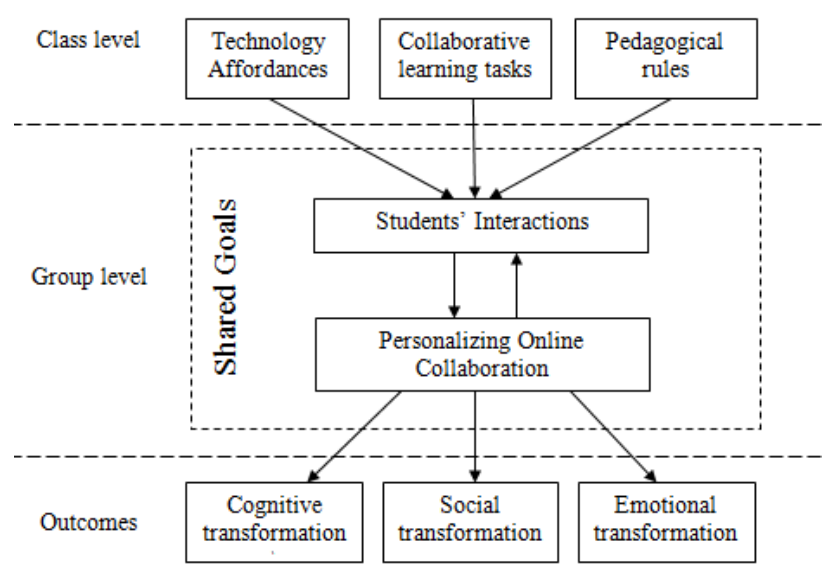

Figure 6. Contextual analytical model for the study 


\section{A. Research Objective:}

The research objective is to evaluate the effectiveness of incorporating online collaborative learning in a classroom learning

\section{B. Samples}

The study was conducted through an ICT education course in a Malaysian university that required online collaborative learning (OCL) discussions for 13 weeks: the first four weeks were intra-group work discussions (Task 1), followed by five weeks of inter-group work discussions (Task 2), and the remaining four weeks were for the final intra-group work discussions (Task 3). The OCL intervention was aimed at facilitating interdisciplinary collaboration and interaction between students from Chemistry, Physics and Mathematics majors through the university's Learning Management System (Moodle), which provided the shared space for the OCL discourse and tools for collaboration. A total of nine groups of four to six students $(\mathrm{N}=46)$ were involved in this study. The students participating in the research were Malaysian undergraduate pre-service teachers from three different programmes of Science and Mathematics, with specialization in Computer Education, namely, Science and Computer with Education (SPK), Science and Computer with Education (SPP), and Science and Computer with Education (SPT). The students in each programme were in the second year of their study and were enrolled in a Computer Education course known as Authoring Language, which was conducted the Department of Educational Sciences, Mathematics and Creative Multimedia, Faculty of Education, Universiti Teknologi Malaysia (see Table 1).

TABLE I.

BACKGROUND OF PARTICIPANTS

\begin{tabular}{lll}
\hline \multicolumn{1}{c}{ Characteristics } & & N \\
\hline Programme of study & SPK-Chemistry & 9 \\
& SPP-Physics & 10 \\
& SPT-Mathematics & 27 \\
\hline Gender & Female & 34 \\
& Male & 12 \\
\hline \multirow{2}{*}{ Ethnicity } & Malay & 38 \\
& Chinese & 4 \\
& Indian & 2 \\
& Other & 2 \\
\hline \multirow{2}{*}{ Age } & 19-23 years & 33 \\
& 24-30 years & 13 \\
\hline \multirow{2}{*}{ Education level } & Undergraduate-Year 2 & 46 \\
\hline
\end{tabular}

\section{FINDINGS AND DISCUSSION}

The overall findings of evaluating the incorporation of online collaborative learning in conventional tertiary classroom revealed a transformation in participation as well as a change in aspects of students' intellectual, social, and emotional development as the course progressed. An overview of findings as they relate to the framework as in Fig. 6 is described next.

The study was intended to evaluate the outcomes of learning for students who participated in an online collaborative learning (OCL) intervention as part of a conventional classroom teaching in a Malaysian university. As students reported, they entered the course with one goal - to pass the course. Over the period of the course, they increasingly participated and became involved in the OCL activities, and became acculturated into the discourse of the OCL within the knowledge community of the class. The students gradually experienced new perspectives on a particular knowledge problem through their interactions with peers; they developed new and deeper understandings and eventually learnt to address their understandings in the manner of the knowledge community. Student A reported:

When I came across this Authoring Language subject, I thought 'Oh my God! It's Computer subject again!' and I expected to be totally frustrated and discouraged by this course. This was what I thought at the beginning of the semester. However, after completing my Authoring Language assignments [online activities], I realized that I love this subject; this actually came from my heart and I don't mean to brag. This was because AL was interesting and an effective instrument for students to enhance their understanding and improve their skills. Finally, now I know how to develop some applications and, do you believe it, I have shown it to my friend from SPC [the other course] and she was impressed and wanted to know more about this course. (Student A)

The findings of this study evaluated the OCL intervention through the contextual analytical framework of activity. The framework evaluated the OCL intervention at three different contextual levels, but complementary to each other. The higher contextual level (class) considered the analysis of the intervention on a broader institutional level within which the intervention operated. It considered the affordance of tools, activities and resources for participation in the course and how these affected students' expectations from the course and how they had achieved the goals. The findings from the broader context of the OCL intervention showed that the OCL tools and activities afforded students' participation and collaboration in the OCL intervention at the class level. The students said that they found the OCL tools and activities helped their collaborative participation, in which they were able to achieve the course goals, improve their knowledge in ICT and computer education, and obtain a good final course grade. Student B highlighted:

To be honest, I am not really fond of a course that is related to computers like this Authoring Language course because my target is just to finish my study and to be a teacher. I learn, not simply to gain knowledge, but just to pass the course. Having said that, I felt that this course changed me in terms of how I felt the impact of this course in so many aspects, especially knowledge of ICT and computer. I also felt that through my interaction with other students, especially female students, gave me opportunities to learn more about Authoring Language and this helped me in my final project courseware. (Student B)

The nature of students' group online interactions in the course was examined at the middle contextual level (group). The analysis also considered how students interacted with one another in supporting and developing their cognitive, social and emotional skills during the intervention to achieve the course goals. The findings from group level showed that the OCL activities that were designed to foster the OCL collaborations as the students learned about the course were helpful in framing students' collaborations for learning from the cognitive, social and emotional perspectives. 
TABLE II.

SAMPLE OF STUDENTS' INTERACTIONS IN DISCUSSION

\begin{tabular}{|c|c|c|}
\hline Group & Online Postings & Types of Interaction \\
\hline \multicolumn{3}{|c|}{ Theme 1: Software compatibility } \\
\hline $\begin{array}{l}\text { Group 3-Student A } \\
\text { (Posting \# 20) }\end{array}$ & $\begin{array}{l}\text { To select appropriate authoring software, we must first look at its compatibility with operat- } \\
\text { ing system such as Windows. For my group, we think PowerPoint in Office } 2008 \text { is now } \\
\text { compatible with Macintosh. }\end{array}$ & $\begin{array}{l}\text { Giving opinion } \\
\text { (Implicit) }\end{array}$ \\
\hline $\begin{array}{l}\text { Group 9- Student B } \\
\text { (Posting \#21) }\end{array}$ & $\begin{array}{l}\text { Yup, we do have to look at the software compatibility with other operating systems than } \\
\text { Windows. }\end{array}$ & $\begin{array}{l}\text { Agreeing } \\
\text { (Implicit) }\end{array}$ \\
\hline $\begin{array}{l}\text { Group 8- Student C } \\
\text { (Posting \#22) }\end{array}$ & $\begin{array}{l}\text { That's right Zuwan, how about Linux? Because in my group, we do have lesson like KIG in } \\
\text { Linux...but if we use Open Office, can we use it on either Windows or Linux? }\end{array}$ & $\begin{array}{l}\text { Posing question } \\
\quad \text { (Explicit) }\end{array}$ \\
\hline $\begin{array}{l}\text { Group 3- Student D } \\
\text { (Posting \# 23) }\end{array}$ & $\begin{array}{l}\text { I would like to confirm operating system uses in school is Windows so no need to fuss over } \\
\text { PowerPoint compatibility. }\end{array}$ & Giving feedback (Implicit) \\
\hline \multicolumn{3}{|l|}{ Theme 2: User-friendly } \\
\hline $\begin{array}{l}\text { Group 2- Student E } \\
\text { (Posting \# 26) }\end{array}$ & $\begin{array}{l}\text { Hi, by using Microsoft PowerPoint } 2008 \text { that means we need to install Windows Vista. } \\
\text { However, most of the software and programmes fail to run perfectly with Windows Vista } \\
\text { while the latest Windows } 7 \text { is yet too unfamiliar with the teachers in school. } \\
\text { What our group suggested earlier Flash is easy to handle and understand which also support } \\
\text { texts, graphics, audio and video. For more details please refer this link: } \\
\text { http://kb2.adobe.com }\end{array}$ & $\begin{array}{l}\text { Suggesting idea } \\
\text { (Implicit) }\end{array}$ \\
\hline $\begin{array}{l}\text { Group1- Student F } \\
\text { (Posting \# 27) }\end{array}$ & $\begin{array}{l}\text { Microsoft PowerPoint office } 2008 \text { is not necessary run in Windows Vista; it also can run in } \\
\text { Windows XP. } \\
\text { Our group agreed with Microsoft PowerPoint because flexibility and easy to use should } \\
\text { become our first priority for consideration. }\end{array}$ & $\begin{array}{l}\text { Giving feedback (Implicit) } \\
\text { Agreeing } \\
\text { (Implicit) }\end{array}$ \\
\hline $\begin{array}{l}\text { Group 5- Student G } \\
\text { (Posting \# 28) }\end{array}$ & $\begin{array}{l}\text { Hmm, its look like many agreed with the use of Open Office but we also need to think for } \\
\text { long term like the duration to learn for the software. }\end{array}$ & $\begin{array}{l}\text { Clarifying idea } \\
\text { (Implicit) }\end{array}$ \\
\hline \multicolumn{3}{|c|}{ Theme 3: Training duration } \\
\hline $\begin{array}{l}\text { Group 7- Student H } \\
\text { (Posting \# 30) }\end{array}$ & $\begin{array}{l}\text { Our group agreed with Open Office or Microsoft PowerPoint because their functions are } \\
\text { same like Microsoft Word which can be learned in short time especially for Mathematics } \\
\text { symbols. }\end{array}$ & $\begin{array}{l}\text { Agreeing } \\
\text { (Implicit) }\end{array}$ \\
\hline $\begin{array}{l}\text { Group 2- Student I } \\
\text { (Posting\# 31) }\end{array}$ & $\begin{array}{l}\text { We need to consider teachers prior knowledge of computer which it is hard on Flash than } \\
\text { PowerPoint. }\end{array}$ & $\begin{array}{l}\text { Giving opinion } \\
\text { (Implicit) }\end{array}$ \\
\hline \multicolumn{3}{|c|}{ Theme 4: External resources and references } \\
\hline $\begin{array}{l}\text { Group 4- Student } \mathrm{J} \\
\text { (Posting \#33) }\end{array}$ & Currently there are many available tutorials for learning PowerPoint. & $\begin{array}{l}\text { Sharing information } \\
\text { (Independent) }\end{array}$ \\
\hline $\begin{array}{l}\text { Group 3- Student K } \\
\text { (Posting\#35) }\end{array}$ & $\begin{array}{l}\text { Eight unit tutorial show how to use PowerPoint to present many different forms of infor- } \\
\text { mation. }\end{array}$ & $\begin{array}{l}\text { Sharing information } \\
\text { (Independent) }\end{array}$ \\
\hline \multicolumn{3}{|c|}{ Theme 5: Software suitability } \\
\hline $\begin{array}{l}\text { Group 5- Student L } \\
\text { (Posting \# 40) }\end{array}$ & $\begin{array}{l}\text { For the conclusion, we from Group } 5 \text { Mathematics suggests for selecting PowerPoint Office } \\
\text { for proposal of Authoring tools for teaching and learning for Science and Mathematics } \\
\text { subject in Sultanah Zanariah school because of the software suitability in fulfilling all the } \\
\text { criteria aspects. }\end{array}$ & $\begin{array}{l}\text { Suggest idea } \\
\text { (Implicit) }\end{array}$ \\
\hline $\begin{array}{l}\text { Group 2- Student M } \\
\text { (Posting\# 41) }\end{array}$ & $\begin{array}{l}\text { Anywhere, our group also agreed for Microsoft PowerPoint suitability for Chemistry sub- } \\
\text { ject learning. }\end{array}$ & $\begin{array}{l}\text { Agreeing } \\
\text { (Implicit) }\end{array}$ \\
\hline $\begin{array}{l}\text { Group 4- Student N } \\
\text { (Posting \# 44) }\end{array}$ & $\begin{array}{l}\text { SPP, Physics groups collectively concurred in the decision for selecting PowerPoint for } \\
\text { teaching and learning. }\end{array}$ & $\begin{array}{l}\text { Agreeing } \\
\text { (Implicit) }\end{array}$ \\
\hline
\end{tabular}

The lower level evaluated the intervention based on its outcomes and constraints with regards to student participation in the OCL activities. The outcomes were marked as cognitive, social and emotional transformations. The findings from the outcomes level showed that students developed understandings and gained expertise, as reported by student $\mathrm{O}$ :

As a learner before I have entered this course, I have never heard of Authorware, let alone the processes of building interactive presentations. My weakness is that I am not highly creative when it comes to building interactive presentations. After entering this course, I have learnt not only about building an interactive presentation but also including other media, display, and so on. These are all available in this course and I am glad that I have participated in it. (Student O)

They also developed more responsibility for their own and others' learning, and developed positive attitudes, gained confidence and felt satisfaction in the course at the end of the semester. Student $P$ reported:

One of our responsibilities is to remind them and care about others participating in discussions because when we discuss we need feedback, so, by reminding other students to participate in the online discussion, we can get responses for those who are online. (Student P)

However, the findings at the outcomes level also revealed some potential constraints and tensions from the OCL intervention such as technology-related contradictions (such as a desire for synchronous feedback in forum discussions, cutting and pasting and plagiarism of ideas, and other technological distractions) and group discussion contradictions (such as repetitive and mixed-up posts, clashes on topics of discussion, and discussions being too formal). 


\section{CONCLUSION}

Boer et al. [1] suggested that when any intervention is evaluated as an activity system in a particular context, its relation to other contextual levels should also be taken into consideration in order to reveal its temporal interconnectedness and outcomes. Although others have extended and applied Activity Theory as analytical framework in other contexts such as human-computer interaction, activity-centered design and the analysis of the situatedness of knowledge sharing, none have specifically applied the framework for evaluating an online collaborative learning (OCL) through different level of contextual analysis [1][3][16]. Hence, this study had developed and applied the use contextual analytical framework for evaluating the outcomes of OCL. The findings in this study included the outcomes of the OCL intervention at three interconnected levels, highlighted the mediation of tools on a broader class contextual level followed by the interactions within the OCL intervention and the outcomes and constraints of the OCL intervention. This resonates with Boer et al.'s [1] idea of the situatedness of knowledge sharing within, and between, different organizational settings for example the industry at high level, the organization at middle level and the department at lower level.

\section{ACKNOWLEDGMENT}

The authors would like to thank the Universiti Teknologi Malaysia (UTM) and Ministry of Education Malaysia (MoE) Malaysia for their support in making this project possible. This work was supported by the Fundamental Research Grant Scheme (Vote No.4F171) initiated by UTM and MoE.

\section{REFERENCES}

[1] Boer, N., van Baalen, P. J., \& Kumar, K. (2002). An activity theory approach for studying the situatedness of knowledge sharing. Paper presented at the Proceedings of the 35th Hawaii International Conference on System Sciences, Hawaii. http://dx.doi.org/10.1109/HICSS.2002.994017

[2] Cohen, L., Manion, L., \& Morrison, K. (2000). Research methods in education (5th ed.). London: RoutledgeFalmer. http://dx.doi.org/10.4324/9780203224342

[3] Daniels, H., \& Gutierrez, K. D. (2009). Learning and expanding with activity theory. New York: Cambridge University Press.

[4] Engeström, Y. (1999). Expansive visibilization of work: An activity-theoretical perspective. Computer Supported Cooperative Work (CSCW), 8(1), 63-93. $\quad$ http://dx.doi.org/10.1023/A: 1008648532192

[5] Engeström, Y. (2001). Expansive learning at work: Toward an activity theoretical reconceptulization. Education and Work, 14(1), 133-156. http://dx.doi.org/10.1007/978-1-4419-1428-6_857

[6] Harasim, L. (2012). Learning Theory and Online Technologies (First ed.). New York: Taylor and Francis Group.

[7] Johnson, D. W., \& Johnson, F. P. (2009). Joining together: Group theory and group skills (Vol. 10). New Jersey: Pearson.

[8] Kuutti, K. (1996). Activity theory as a potential framework for human-computer interaction research. In B. Nardi (Eds.), Context and consciousness: Activity theory and human computer interaction (pp. 17-44). Cambridge: MIT press.

[9] Mason, \& Rennie, F. (2008). E-learning and social networking Handbook: Resources for higher education. New York, USA: Routledge.

[10] Mohamad Said, M. N. H. (2013). Online collaborative learning in tertiary ICT education to enhance students' learning in Malaysia. Unpublished doctoral dissertation, University of Waikato, Hamilton, New Zealand.

[11] Mohamad Said, M. N. H., Forret, M., \& Eames, C. (2013). Online Collaborative Learning in Tertiary ICT Education: Constraints and Suggestions for Improvement. Informatics and Creative Multimedia (ICICM'13), pp.153,158. http://dx.doi.org/10.1109/ICICM. 2013.33

[12] Mohamad Said, M. N. H., Forret, M., \& Eames, C. (2014). Analysis of Contradictions in Online Collaborative Learning using Activity Theory as Analytical Framework. Jurnal Teknologi, 68(2). doi: http://dx.doi.org/10.11113/jt.v68.2910

[13] Palloff, M. R., \& Pratt, K. (2005). Collaborating online: Learning together in community. San Francisco: Jossey-Bass.

[14] Rogoff, B. (2003). The cultural nature of human development. Oxford, NY: Oxford University Press.

[15] Wenger, E. C., White, N., \& Smith, J. D. (2009). Digital habitats: Stewarding technology for communities. CPsquare.

[16] Yamagata-Lynch, L. C. (2010). Activity systems analysis methods: Understanding complex learning environments. New York: Springer. http://dx.doi.org/10.1007/978-1-4419-6321-5

\section{AUTHORS}

Mohd Nihra Haruzuan Mohamad Said, Ph.D, Department of Educational Sciences, Mathematics and Creative Multimedia, Faculty of Education, Universiti Teknologi Malaysia, Malaysia (e-mail: nihra@utm.my, corresponding author)

Lokman Mohd Tahir, PhD, Department of Educational Foundation, Faculty of Education, Faculty of Education, Universiti Teknologi Malaysia, Malaysia (e-mail: plokman@utm.my)

Mohd Fadzli Ali, MSc (Media), Department of Educational Sciences, Mathematics and Creative Multimedia, Faculty of Education, Universiti Teknologi Malaysia, Malaysia (e-mail: p-fadzli@utm.my)

Norah Md Noor, MSc (Computer), Department of Educational Sciences, Mathematics and Creative Multimedia, Faculty of Education, Universiti Teknologi Malaysia, Malaysia (e-mail: norah@utm.my)

Noor Azean Atan, PhD, Department of Educational Sciences, Mathematics and Creative Multimedia, Faculty of Education, Universiti Teknologi Malaysia, Malaysia (email: azean@utm.my)

Zaleha Abdullah, PhD, Department of Educational Sciences, Mathematics and Creative Multimedia, Faculty of Education, Universiti Teknologi Malaysia, Malaysia (email: zac@utm.my)

This work was supported in part by (Fundamental Research Grant Scheme (Vote No.4F171) initiated by UTM and MoE).Submitted, June, 17, 2014. Published as resubmitted by the authors on August, 19, 2014. 